\title{
Uzaktan algılama ve CBS teknikleri kullanılarak Seyfe Gölü (Kırşehir) yüzey alanının zamansal değişiminin analizi
}

\author{
Analysis of temporal changes on the surface area of the Seyfe Lake (Kirşehir) using remote \\ sensing and GIS techniques
}

\author{
Cansu YURTERİ*1,a, Türker KURTTAȘ ${ }^{1, b}$ \\ ${ }^{1}$ Hacettepe Üniversitesi, Mühendislik Fakültesi, Hidrojeoloji Mühendisliği, 06800, Ankara
}

• Geliş tarihi / Received: 29.12.2020 • • • Düzeltilerek geliş tarihi / Received in revised form: 30.06.2021 • Kabul tarihi / Accepted: 16.07 .2021

\begin{abstract}
Öz
Bu çalışmanın amacı çok bantlı uydu görüntüleri ile Seyfe Gölü yüzey alanının zamansal değişiminin Uzaktan Algılama (UA) ve Coğrafi Bilgi Sistemleri (CBS) teknikleri ile incelenmesidir. Çalışma alanı olan Seyfe Gölü, $1447 \mathrm{~km}^{2}$ lik yüzey drenaj alanına sahip Seyfe Havzasında yer almaktadır. Kapalı bir havzada yer alan göl alanının beslenimi yağış, yüzeysel akış ve akifer birimlerden beslenim ile gerçekleşmektedir. Gölün boşalımı ise, göl yüzeyinden buharlaşma ve drenaj kanalları ile gerçekleşmektedir. Bu çalı̧̧mada 1985-2020 yılları arasındaki Landsat çok bantlı uydu görüntüleri (Landsat 5 TM, Landsat 8 OLI/TIRS) kullanılmışıır ve her beş yıl için bir görüntü seçilmiştir. Uydu görüntülerinden türetilen Modifiye Edilmiş Normalize Fark Su İndeksi (MNDWI) yöntemi kullanılarak farklı yıllarda göl yüzey alanındaki değişimler hesaplanmıştır. 1985-2020 yılları arasında MNDWI yöntemi ile maksimum ve minimum göl alanları sırasıyla $66.87 \mathrm{~km}^{2}$ ve $1.86 \mathrm{~km}^{2}$ olarak hesaplanmıştır. 35 yılık süreçte, göl alanında \% 93.78' lik bir azalma olduğu belirlenmiştir. Batimetri çalışmaları kapsamında ise; Devlet Su İşleri (DSI) tarafından 2015 yılında hazırlanan göl hidrografik haritasındaki göl tabanı seviye ölçümlerinden göl batimetri haritası oluşturulmuştur. Göl alanının kot, hacim ve alan ilişkisinin belirlenmesine yönelik analizler gerçekleştirilmiştir. Oluşturulan göl batimetri haritasına göre; maksimum derinlik göl alanının kuzeyinde 1.95 m olarak hesaplanmıştır.
\end{abstract}

Anahtar kelimeler: Göl alanı, Göl batimetrisi, MNDWI, Seyfe Gölü, Uzaktan algılama

\begin{abstract}
The aim of the study is to investigate temporal changes on the surface area of the Seyfe Lake with multispectral satellite images by using Remote Sensing (RS) and Geographical Information Systems (GIS) techniques. Lake Seyfe, a study area, is located in the Seyfe Basin with a catchment area of $1447 \mathrm{~km}^{2}$. The closed basin of Seyfe Lake is recharge by precipitation, surface runoff and from surrounding aquifer units. Discharge of the lake takes place through evaporation and drainage channels. Landsat multispectral satellite images (Landsat 5 TM and Landsat 8 OLI/TIRS) are used in this study; with one scene selected for every five years ranging between 1985-2020. The Modified Normalized Difference Water Index (MNDWI) method is used to delineate the lake boundaries and the changes in the lake surface area for the respective years calculated. Based on the MNDWI method, maximum and minimum surface area measurements of the Seyfe Lake are found to be $66.86 \mathrm{~km}^{2}$ and $1.86 \mathrm{~km}^{2}$, respectively in between 1985-2020. It was determined that the lake surface area decreased by $93.78 \%$ during this 35 year period. Within the scope of bathymetry studies; the elevation of the lake bottom is derived from the hydrographic map of the lake area prepared by General Directorate of State Hydraulic Works (DSI) in 2015. Analyses were carried out to establish the relationship between elevation, surface area and volume of the lake body. According to the bathymetric map, maximum depth was calculated in the northern part of the lake and is around $1.95 \mathrm{~m}$.
\end{abstract}

Keywords: Lake area, Lake bathymetry, MNDWI, Seyfe Lake, Remote sensing

\footnotetext{
${ }^{*}$ Cansu YURTERİ; cyurteri@hacettepe.edu.tr, Tel: (0312) 297 77 00-169, orcid.org/0000-0002-4944-0168

${ }^{\mathrm{b}}$ orcid.org/0000-0003-1426-566X
} 


\section{Giriş}

Günümüzde kurak-yarıkurak bölgelerdeki iklimsel değişimler, artan su ihtiyacı ve insan faaliyetlerinin etkisi nedeniyle kuruyan, gittikçe küçülen veya yok olan su kaynakları ve su kütlelerinin sayısı gittikçe artmaktadır (Kiage ve Douglas, 2019). Bu su kütlelerindeki konumsal ve zamansal değişikliklerin yerel ve bölgesel ekosistemler ile sosyoekonomik faaliyetler üzerinde de önemli etkileri mevcuttur (Kiage ve Douglas, 2019). Göller ve sulak alanlar iklimsel değişimler ile antropojenik etkilerden belirgin bir şekilde etkilenen hassas su kütleleridir (Chang vd., 2017). Dolayısıyla hidrolojik çalışmalarda göl, gölet, baraj ve sulak alan gibi su kütlelerindeki değişimlerin izlenmesinde Uzaktan Algılama (UA) ve Coğrafi Bilgi Sistemleri (CBS) tekniklerinden yaygın bir şekilde yararlanılmaktadır. $\mathrm{Bu}$ tekniklerin birlikte kullanılması, zaman içerisinde değişime uğrayan su kütlelerinin uzun zaman periyotlarında hızlı ve doğru bir şekilde izlenmesine olanak sağlamaktadır (Bao ve Zhang, 2011). UA ve CBS teknikleri, çok bantlı uydu görüntülerinin analiz edilerek su kütlelerinin çıkarılması, alansal değişimlerinin belirlenmesi, kıyı kenar çizgisi değişiminin saptanması, arazi bitki örtüsünün belirlenmesine yönelik araştırmalar ile hidrolojik gözlemlerde yaygin olarak kullanılmaktadır (Howari vd., 2007). Yine bu yöntemler su kaynaklarının araştırılması, belirlenmesi ve izlenmesine bir yaklaşım getirirken, çeşitli su kütleleri için seviye, hacim ve alan parametrelerinin saptanmasinda da kullanılabilmektedirler (Dost ve Mannaerts, 2005). Uydu görüntüleri aracıllığıla gerçekleştirilen UA ve CBS çalışmaları, hassas ekosistemlere sahip su kütlelerindeki meydana gelen zamansal ve konumsal değişimlerin erkenden belirlenmesi ve olas1 problemlerde tedbirlerin önceden alınması için oldukça pratik, etkili ve düşük maliyetli teknolojik araçlardır (Howari vd., 2007).

Hassas alanların sürdürülebilirliği için izleme çalışmalarında ve olası afetleri önleme kapsamında yapılan araştırmalarda da uydu görüntülerinden sıklıkla yararlanıldığı görülmektedir (Mutlu vd., 2020; Gülci vd., 2019; Kiage ve Douglas, 2019; Gautam vd., 2015; Deus ve Gloaguen, 2013; El Asmar vd., 2013; Fang Fang vd., 2011). Gelişen teknolojiyle birlikte Türkiye ve Dünya'nın çeşitli bölgelerindeki su ile kaplı alanlar, çok bantlı uydu görüntülerindeki bantların oranlanmasını temel alan su indisi eşitlikleri ile belirlenebilmektedir (Gao, 1996., McFeeters, 1996; Xu, 2006). Literatürde spektral su indisleri kullanılarak su kütlelerindeki değişimler ile su-kara yüzeylerinin doğru bir şekilde belirlenmesine yönelik birçok çalışma mevcuttur (Nandi vd., 2019; Ali vd., 2019; Naik ve Anuradha, 2018; Zhai vd., 2015; El Asmar vd., 2013).

Nandi vd. (2019) yapmış oldukları çalışmada Hindistan'ın doğu kıyısında yer alan ve bir Ramsar alanı olan Chilika Gölü su yüzey alanındaki değişimleri çeşitli spektral su indisleri yöntemleriyle incelemişlerdir. Çalışmada 1995, 1996, 1997, 2013 ve 2014 y1llarının kurak ve yağışlı dönemlerine ait çok zamanlı Landsat uydu görüntüleri kullanılmıştır. Görüntülere Normalize Edilmiş Fark $\mathrm{Su}$ İndeksi (NDWI), Modifiye Edilmiş Normalize Fark Su İndeksi (MNDWI) ve Otomatik Su Çıkarma İndeksi (AWEI) yöntemleri uygulanmıştır. MNDWI yönteminin, diğer su indislerine (NDWI, AWEI) göre su ve kara yüzey alanlarının ayrılmasında daha etkin ve yüksek doğruluklu sonuçlar verdiği belirtilmiştir.

Ali vd. (2019) Endonezya' daki Makasar şehrindeki su kütlelerinin 2000-2019 yılları arasında yüzey alanındaki değişimlerini, Landsat uydu görüntüleri ve spektral su indisleri kullanarak incelemişlerdir. Yapılan araştırmada NDWI ve MNDWI su indisleri kullanılmıştır. $\mathrm{Bu}$ yöntemlerde sınıflandırma işlemi, su kütlesi ile kaplı olan ve olmayan alanlar olarak iki alt sinıfa ayrilarak yapılmıştır. MNDWI yöntemi kullanılarak gerçekleştirilen analizlerde, toprak ve yerleşim yeri etkilerinin azaldığını ve su kütlelerini belirlemede MNDWI yönteminin NDWI yöntemine göre daha etkili sonuçlar verdiği belirtilmektedir. Ayrıca şehrin kıyı bölgelerinde yerleşim yerlerinin artması nedeniyle 2000-2019 y1lları arasinda su kütlelerinde azalmanın gerçekleştiği belirlenmiştir.

Naik ve Anuradha (2018) çalışmalarında Hindistan'da yer alan Nagarjuna Sagar Baraj Gölü'nün kapladığı su yüzey alanının 1989-2017 yılları arasındaki zamansal değişiminin spektral su indisleri kullanilarak belirlenmesini amaçlamışlardır. Baraj Gölü yüzey alanında 28 yıllık değişimin saptanması amacıyla Landsat uydu görüntülerine çeşitli su indisleri uygulanarak doğruluk analizleri gerçekleştirilmiştir. Spektral su indislerinin analiz sonuçlarına göre; MNDWI yönteminin diğer su indeksi (NDWI, AWEI) yöntemlerine kıyasla su kütlelerinin çıkarılmasında çok daha iyi sonuçlar sağladığı belirtilmiştir. Çalışmada MNDWI yöntemine göre yapılan analizin genel doğruluk yüzdesi \%96.43, Kappa Katsayısı ise 0.89 olarak hesaplanmıştır.

Zhai vd. (2015) tarafından yapılan çalışmada Çin'in kuzeyinde Bohai Körfezi yakınlarında yer 
alan Tianjin ve Nanyang Pier yerleşim alanlarının arazi örtüsü değişimlerinin belirlenmesi amaçlanmıştır. Buna göre çok bantlı Landsat 8 OLI ve Landsat 5 TM uydu görüntülerine Normalize Edilmiş Fark Bitki Örtüsü İndeksi (NDVI), NDWI, MNDWI ve AWEI yöntemleri uygulanmıştır. Çalışmada MNDWI yönteminin su kütleleri ile diğer arazi sınıflarının ayrılmasında diğer yöntemlere göre oldukça başarılı sonuçlar veren bir teknik olduğu belirtilmiştir. NDVI ve NDWI yöntemlerinin yerleşim yerleri, toprak örtüsü ile doğal çayırlık alanların birbirlerinden ayırt edilmesinde etkili sonuçlar veremediği belirtilmiştir. El Asmar vd. (2013) Mısır'daki Burullus Lagünü'nün 1973-2011 yılları arasında yüzey alanındaki değişimi NDWI ve MNDWI su indisleri yaklaşımıyla incelemişlerdir. Lagünün yüzey alanının zamansal değişiminin belirlenmesinde MNDWI yönteminin daha etkili bir yöntem olduğu belirtilmiş ve lagünün yüzey alanının \%42.8 oranında azaldığ

Çalışma alanı ve yakın çevresinde ise UA ve CBS tekniklerine yönelik çalışmalar incelendiğinde sınırlı sayıda çalışmanın olduğu görülmüştür. Yilmaz ve Reis (2008) tarafindan yapilan çalışmada araştırıcılar Seyfe Gölü'nün 1975, 1987 ve 2001 y1llarına ait uydu görüntülerini inceleyerek görsel yorumlama ve kontrolsüz sinıflandırma yöntemleri ile göl alanındaki değişimi incelemişlerdir ve göl su rezervinde bir azalmanın olduğunu tespit etmişlerdir. Yaman ve Avdan (2018) tarafından gerçekleştirilen çalışmada ise araştırıcılar 1986-2017 yılları arasında farklı yıllara ait Landsat uydu görüntüleri ile Seyfe Gölü'nün zaman ve alansal boyutta değişimini NDWI yöntemi ile incelemişler ve göl yüzey alanının her geçen y1l gittikçe küçüldüğü sonucuna varmışlardır.

$\mathrm{Bu}$ çalışmada Seyfe Gölü yüzey alanının 19852020 yılları arasındaki değişiminin analizinde UA ve CBS teknikleri birlikte uygulanmıştır. Uzaktan algılama verisi olarak Landsat çok bantlı uydu görüntüleri (Landsat 8 OLI/TIRS, Landsat 5 TM) kullanılarak göl yüzey alanının 1985, 1990, 1995 , $2000,2005,2010,2015$ ve 2020 yıllarındaki değişimi Xu (2006) tarafından önerilen MNDWI yöntemi ile incelenmiştir. Bu yaklaşımın ayrıntıları Materyal ve yöntem bölümünde sunulmuştur. Göl batimetri çalışmaları kapsamında ise Devlet $\mathrm{Su}$ İşleri Genel Müdürlüğü (DSİ) tarafindan hazırlanan Seyfe Gölü hidrografik haritası değerlendirilerek göl batimetri haritas1 oluşturulmuştur. Buna göre gölün kot, derinlik, hacim ve alan ilişkilerinin belirlenmesine yönelik hesaplamalar gerçekleştirilmiştir. Yapılan analizler ile 1985-2020 yılları arasında göl alanındaki değişimlerin saptanması hedeflenmiştir.

\section{Materyal ve yöntem}

\section{1. Çalışma alanı}

Çalışma alanı Kırşehir ilinin kuzeydoğusunda, Mucur ilçesine $30 \mathrm{~km}$ mesafede yer alan Seyfe Gölü ve yakın çevresini kapsamaktadır. $39^{\circ} 11^{\prime}$ $39^{\circ} 14^{\prime}$ Kuzey enlemleri ile $34^{\circ} 22^{\prime}-34^{\circ} 30^{\prime}$ Doğu boylamları arasında yer alan Seyfe Gölü, $1447 \mathrm{~km}^{2}$ ' lik yüzey drenaj alanına sahip Seyfe Havzasında yer almaktadır. Seyfe Havzası Kızılırmak Havzası'nın alt havzalarından biri olup, kapalı havza özelliğindedir (Sayhan, 2001). Seyfe kapalı havzas1 kuzeybat1 güneydoğu uzanımlıdır. Havzanın topoğrafik olarak en düşük kota sahip yeri Seyfe Gölü'dür (Şekil 1). Seyfe Gölü'nün denizden ortalama yüksekliği 1110 m'dir (Sayhan, 2001).

1/25.000 ölçekli topoğrafik haritalarda J32-c1 ve J32-c2 paftalarında yer alan göl alanı içerisindeki adalarda ve çevresinde $1110 \mathrm{~m}$ ile $1122 \mathrm{~m}$ arasında değişen yükseltiler bulunmaktadır. Gölün DoğuBat1 yönündeki maksimum uzunluğu yaklaşı $11.90 \mathrm{~km}$, Kuzey-Güney yönündeki maksimum genişliği ise $5.86 \mathrm{~km}$ 'dir. Seyfe Gölü Oligosen sonrası oluşmuş sığ bir göl olup, göl alanı ve çevresi 1989 yılında "Doğal Sit Alanı", 1990 y1lında “Tabiatı Koruma Alanı" ve 1994 yılında ise Ramsar Alanı olarak ilan edilmiştir (URL-1, 2020).

Havzada yapılan hidrojeolojik incelemeler kapsamında; kapalı bir havzada yer alan göl alanının beslenimi yağış, yüzeysel akış ve akifer birimlerden gerçekleşmektedir. Gölün boşalımı ise göl yüzeyinden buharlaşma, süzülme ve drenaj kanalları ile gerçekleşmektedir. Göl suları tuzlu ve bazik olup, 2019-2020 y1lları arasında yapılan periyodik ölçümlerde, göl alanı ile bağlantılı drenaj kanallarında Özgül Elektriksel İletkenlik $\left(\ddot{O ̈ E I}_{25^{\circ} \mathrm{C}}\right)$ değeri 29.500-30.500 $\mu \mathrm{S} / \mathrm{cm}$ arasında değişirken, $\mathrm{pH}$ değeri ise 8.61-9.08 arasında değişmektedir. Göl sularındaki tuzluluğun kaynağının gölün kapalı bir havzada yer alması, buharlaşma miktarının fazla olması ve göl havzasında yer alan litolojik birimlerin etkisi gibi faktörler nedeniyle geliştiği düşünülmektedir.

\subsection{Veriler ve yöntem}

Bu çalışmada 1985-2020 yılları arasında Seyfe Gölü yüzey alanında meydana gelen değişimler UA ve CBS teknikleri kullanılarak MNDWI yöntemi ile analiz edilmiştir. 


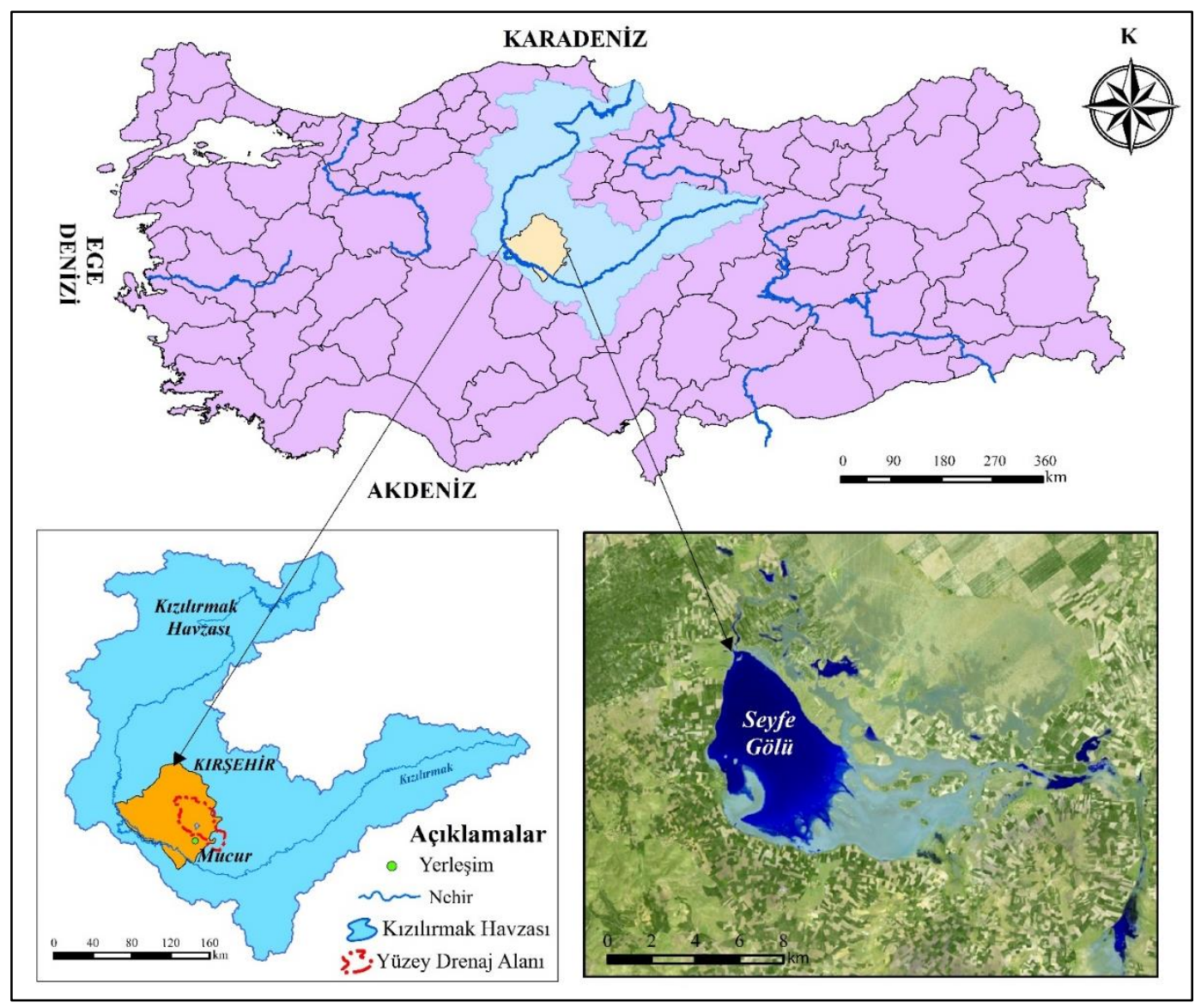

Şekil 1. Çalışma alanı ve yakın çevresi

Ayrıca göl alanının hidrografik haritası temel alınarak arazide ölçülen veriler CBS yazılımına aktarılarak göl alanının batimetri haritası oluşturulmuştur. Göl alanında kot, derinlik, hacim ve alan ilişkisini belirlemeye yönelik alansal ve hacimsel değişimler ArcMap 10.4.1 yazılımının 3 boyutlu fonksiyonel yüzey oluşturma modülü ile hesaplanmıştır.

Göl yüzey alanının MNDWI yöntemi kullanılarak zamansal değişiminin belirlenmesine ilişkin akış şeması aşağıda verilmiştir (Şekil 2).

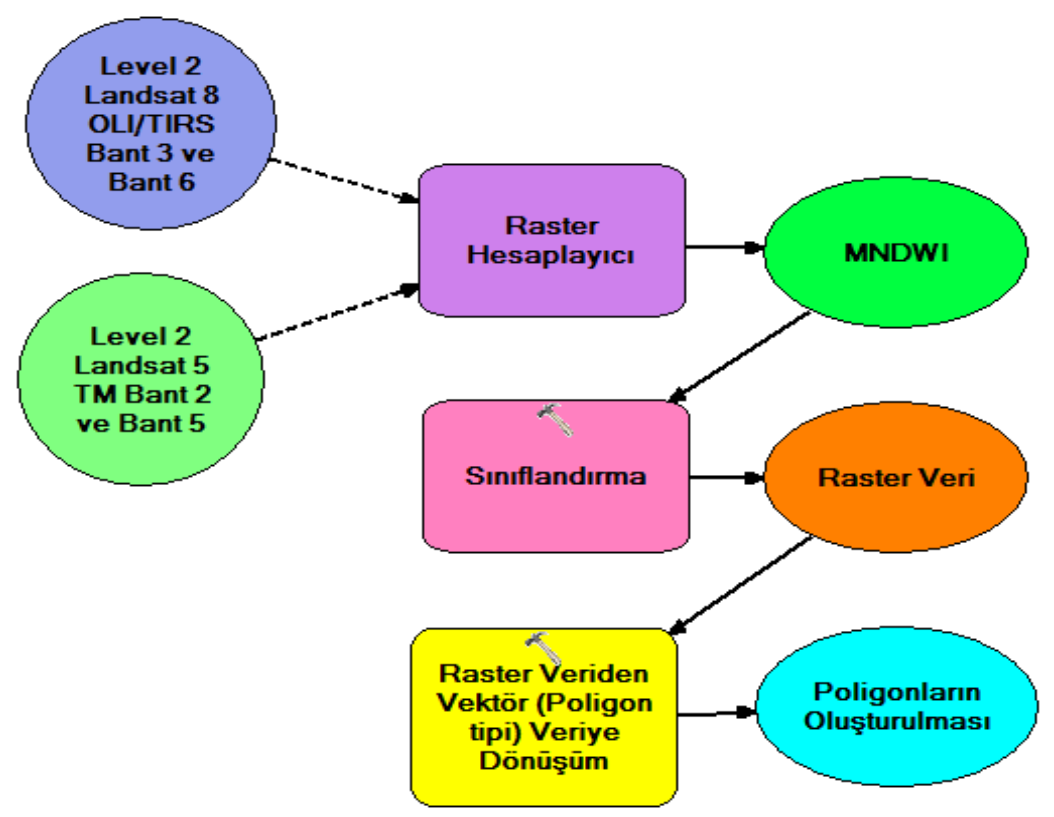

Şekil 2. Uydu görüntüleri ile göl yüzey alanının MNDWI yöntemi ile belirlenmesine yönelik akış şeması 
Çalışma kapsamında uzaktan algılama verisi olarak çok bantlı Landsat uydu görüntüleri kullanılmıştır. Havza ölçeğinde su kütlelerindeki ve arazi örtüsündeki alansal ve zamansal değişikleri araştırmak için Landsat çok bantlı uydu görüntüleri önemli bilgiler içeren ücretsiz veri kaynaklarıdır (Howari vd., 2007). Uydu görüntüleri Amerika Birleşik Devletleri Yerbilimleri Araştırma Kurumu'nun (USGS) Earth Explorer portalından indirilmiştir (URL-2, 2020). Uzaktan algılama verisi olarak, Earth Explorer portalındaki atmosferik, radyometrik ve geometrik düzeltilmesi yapılmış Landsat Level-2 görüntüleri kullanılmıştır. 176/033 yörünge/satır numaralı, 30 metre mekansal çözünürlüğe, 16 gün zamansal çözünürlüğe, 8 ve 16 bit radyometrik çözünürlüklere sahip Landsat- 5 TM ve Landsat-8 OLI çok bantlı uydu görüntüleri seçilmiştir. Ayrıca göl alanının yüzeysel değişiminin belirlenmesi amaciyla, 1985-2020 yılları arasinda kullanilan tüm uydu görüntüleri beşer yıllık dönemlerle bulutluluk oranı \%10'dan küçük olacak şekilde seçilmiştir. Zamansal göl yüzey alanı değişiminin temsil edici bir şekilde belirlenebilmesi için tüm görüntüler yılın kurak ve aynı dönemlerine gelecek şekilde seçilmiştir. Bütün görüntüler o yılın Eylül ayının son iki haftası ile Ekim ayının ilk haftasına aittir. (Tablo 1).

Tablo 1. Çalışma alanının değerlendirilmesinde kullanılan uydu görüntüleri ve özellikleri

\begin{tabular}{ccccccc}
\hline $\begin{array}{c}\text { Algılama } \\
\text { tarihi }\end{array}$ & $\begin{array}{c}\text { Yörünge/ } \\
\text { satır }\end{array}$ & Uydu/Sensör & $\begin{array}{c}\text { Bant } \\
\text { sayısı }\end{array}$ & $\begin{array}{c}\text { Radyometrik } \\
\text { çözünürlük }\end{array}$ & $\begin{array}{c}\text { Mekansal } \\
\text { çözünürlük }\end{array}$ & $\begin{array}{c}\text { Zamansal } \\
\text { çözünürlük }\end{array}$ \\
\hline 23.09 .1985 & $176 / 033$ & Landsat5 TM & 7 & $8 \mathrm{bit}$ & $30 \times 30 \mathrm{~m}$ & 16 gün \\
21.09 .1990 & $176 / 033$ & Landsat5 TM & 7 & $8 \mathrm{bit}$ & $30 \times 30 \mathrm{~m}$ & 16 gün \\
05.10 .1995 & $176 / 033$ & Landsat5 TM & 7 & $8 \mathrm{bit}$ & $30 \times 30 \mathrm{~m}$ & 16 gün \\
16.09 .2000 & $176 / 033$ & Landsat5 TM & 7 & $8 \mathrm{bit}$ & $30 \times 30 \mathrm{~m}$ & 16 gün \\
14.09 .2005 & $176 / 033$ & Landsat 5 TM & 7 & $8 \mathrm{bit}$ & $30 \times 30 \mathrm{~m}$ & 16 gün \\
28.09 .2010 & $176 / 033$ & Landsat 5 TM & 7 & $8 \mathrm{bit}$ & $30 \times 30 \mathrm{~m}$ & 16 gün \\
26.09 .2015 & $176 / 033$ & Landsat 8 OLI & 9 & $16 \mathrm{bit}$ & $30 \times 30 \mathrm{~m}$ & 16 gün \\
23.09 .2020 & $176 / 033$ & Landsat 8 OLI & 9 & $16 \mathrm{bit}$ & $30 \times 30 \mathrm{~m}$ & 16 gün \\
\hline
\end{tabular}

\subsection{MNDWI (Modifiye Edilmiş Normalize Fark Su Indeksi) yöntemi}

Uzaktan algılama çalışmalarında uydu görüntüleri üzerinden arazide bulunan su kütlelerinin diğer arazi kullanımı ve örtüsünden (yerleşim, bitki örtüsü, toprak vb.) daha kolay ayrılması için farklı sınıflama ve su kütlesi ayırma yöntemleri (NDWI, MNDWI, AWEI vb. su indisleri) geliştirilmiştir. NDWI, MNDWI, AWEI vb. gibi teknikler seçilen bantların dalga boylarının farkı ile toplamlarının oranlaması ile elde edilmiş su indisleri olup, günümüzde çeşitli su kütleleri için pratik bir şekilde uygulanmaktadır. Özellikle göl ve sulak alan çalışmalarında su indisleri kullanılarak bantların oranlanmasını temel alan yöntemlerden en yaygın kullanılanları NDWI ve MNDWI teknikleridir. Bu yöntemlerden Normalize Edilmiş Fark Su İndeksi (NDWI), McFeeters (1996) tarafindan geliştirilmiştir. $\mathrm{Bu}$ yöntemde su yüzeylerinin toprak ve bitki örtüsünden ayrılması amaçlanmıştır. Buna göre; su kütlelerinin ışığın yeşil dalga boyunun suyu yansıtma ve yakın kızıl ötesi (NIR) bölgede soğurma özelliklerini temel alan bantlar kullanılmıştır. Bu kapsamda Yeşil dalga boyu ile Yakın Kızılötesi dalga boyunun farkı ile toplamının oranlanması sonucu su kütleleri belirlenmektedir. Bu bantların farkı ile toplamına oranı kullanılmaktadır. Su indisi analizlerinde kullanılan çok bantlı uyduların özellikleri Tablo 2'de verilmiştir.

NDWI analizi ile elde edilen görüntü birimsiz -1 ve +1 arasındaki değerleri temsil ederken; 1 ve 1 'den büyük değerler su ile kaplı yerleri göstermektedir. $\mathrm{Bu}$ indisin eşitliği literatürde şu şekilde belirtilmektedir (McFeeters, 1996) (Eşitlik 1).

NDWI $=($ Yeşil Bant-Yakın Kızı̈ötesi Bant $) /$ (Yeşil Bant+Yakın Kızı̈ötesi Bant)

McFeeters (1996) çalışmasından sonra Xu (2006) yapmış olduğu çalışma ile NDWI indisini geliştirmiş ve MNDWI yöntemini önermiştir. $\mathrm{Bu}$ yöntemde su ile kaplı alanların daha net belirlendiği, geçirimsiz yüzeylerin ve bitkilerin net ayrılabildiği, toprak, arazi ve yerleşim yerlerinin etkilerinin azaldığı ve arazi objelerindeki gölge etkisinin kaybolduğu ortaya konulmuştur (Gao, 1996; Haibo vd., 2011; Zhou vd., 2015). Dolayısıyla Xu (2006) geliştirdiği MNDWI yönteminin, NDWI yöntemi ile elde edilen sonuçlara göre su yüzeylerinin belirlenmesinde daha etkili sonuçlar elde ettiği belirlenmiştir. 
Tablo 2. Landsat 8 OLI/TIRS ve Landsat 5 TM uydu görüntülerinin bantları ve özellikleri

\begin{tabular}{|c|c|c|c|}
\hline \multicolumn{2}{|c|}{ Landsat 8 OLI/TIRS (2012-2018) } & \multicolumn{2}{|c|}{ Landsat 5 TM (1984-2011) } \\
\hline Bantlar & Dalga boyu $(\mu \mathrm{m})$ & Bantlar & Dalga boyu $(\mu \mathrm{m})$ \\
\hline Bant 1-Kiy1 Aerosol & $0.43-0.45$ & Bant 1-Mavi & $0.45-0.52$ \\
\hline Bant 2-Mavi & $0.45-0.51$ & Bant 2-Yeşil & $0.52-0.60$ \\
\hline Bant 3-Yeşil & $0.53-0.59$ & Bant 3-Kırmızı & $0.63-0.69$ \\
\hline Bant 4-Kırmızı & $0.64-0.67$ & Bant 4-Yakın Kızılötesi & $0.76-0.90$ \\
\hline Bant 5-Yakın Kızılötesi & $0.85-0.88$ & Bant 5-Orta Kızılötesi & $1.55-1.75$ \\
\hline Bant 6-SWIR-1 & $1.57-1.65$ & Bant 6-Termal Kızılötesi & $10.40-12.50$ \\
\hline Bant 7-SWIR-2 & $2.11-2.29$ & Bant 7-Kısa dalga Kızılötesi & $2.08-2.35$ \\
\hline Bant 8-Pankromatik & $0.50-0.68$ & & \\
\hline Bant 9-Cirrus & $1.36-1.38$ & & \\
\hline Bant 10-TIRS-1 & $10.6-11.19$ & & \\
\hline Bant 11-TIRS-2 & $11.50-12.51$ & & \\
\hline
\end{tabular}

MNDWI yönteminde NDWI'da kullanılan Yakın Kızılötesi bandının (NIR) yerine Orta Kızılötesi bant (MIR) kullanılmıştır. Çünkü bu yöntemde 1şık suda MIR bandı bölgesinde NIR bölgesine kıyasla daha çok absorbe edilmektedir. Yeşil bant maksimum su yüzeyini yansıtırken, Orta Kızılötesi bant su içermeyen arazi objelerini göstermektedir (Deus and Gloaguen, 2013). Bu kapsamda MNDWI analizinde; Yeşil dalga boyu ve Orta Kızılötesi dalga boyunun fark1 ile toplamının oranlanması sonucu su kütlelerinin ayrilması gerçekleşmektedir (Şekil 2). MNDWI analizinde Landsat 5 TM görüntülerinin 2 (Yeşil-(0.52-0.60

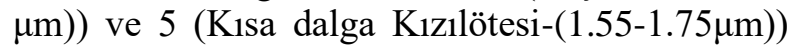
bantları, Landsat 8 OLI/TIRS görüntülerinin OLI sensöründe 3 (Yeşil-(0.53-0.59 $\mu \mathrm{m})$ ) ve 6 (SWIR1$(1.57-1.65 \mu \mathrm{m}))$ bantları kullanılmaktadır. $\mathrm{Bu}$ bantların fark1 ile toplamının oranlaması ile MNDWI analizi gerçekleşmektedir. $\mathrm{Bu}$ indisin eşitliği literatürde Landsat $5 \mathrm{TM}$ ve Landsat $8 \mathrm{OLI}$ uydu görüntülerinin kullanılan bantlarına göre aşağıdaki şekilde uygulanmaktadır (Xu, 2006) (Eşitlik 2 ve 3).

Landsat $5 \mathrm{TM}_{\text {MNDWI }}=($ Yeşil Bant-Orta Kızılötesi Bant)/(Yeşil Bant+Orta Kızılötesi Bant)

Landsat $8 \mathrm{OLI}_{\mathrm{MNDWI}}=($ Yeşil Bant-Kısa dalga Kızılötesi Bant)/(Yeşil Bant+Kısa dalga Kızı̈ötesi Bant)

Xu (2006) tarafından önerilen MNDWI eşitliği ile elde edilen görüntüde 0 ve 0 'dan büyük pozitif değerler su ile kaplı alanlar, 0'dan küçük negatif değerler ise karasal alanlar (yerleşim, toprak, arazi bitki örtüsü vb.) olarak tanımlanmıştır.

$\mathrm{Bu}$ çalışmada göllerde ve sulak alanlarda su kütlelerinin çıkarılması çalışmalarında (Gautam vd., 2015) oldukça etkili sonuçlar verdiği belirtilen
MNDWI yöntemi kullanılmıştır. Buna göre farklı yıllarda göl yüzeyinin kapladığı alanının ve değişiminin belirlenmesinde MNDWI yöntemi uygulanmıştır. Göl alanının su ile kaplı olduğu kesimlerin belirlenmesine yönelik tüm analiz ve hesaplamalar ArcMap 10.4.1 yazılımı ile gerçekleştirilmiştir.

\section{Bulgular}

\subsection{MNDWI yöntemi ile Seyfe Gölü yüzey alanının zamansal değişiminin analizi}

Seyfe Gölü'nün kapladığı su yüzey alanı MNDWI yöntemi ile analiz edilmiştir. (Şekil 4). Göl alanının analiz edilen zaman serisi içerisinde, 1990 y1lında en geniş yüzey alanına sahip olduğu belirlenmiş ve $66.87 \mathrm{~km}^{2}$ olarak hesaplanmıștır. 2020 y1lında ise göl yüzey alanı $1.86 \mathrm{~km}^{2}$ 'ye kadar düşmüştür. $\mathrm{Bu}$ 35 yıllık süreçte; göl alanının 1985 yılından 1990 yılına kadar genişlediği, 1990 yılında göl alanının maksimum seviyeye ulaştığı, 1995 yılından 2015 yılına kadar gölün gittikçe küçüldüğü belirlenmiştir. 2015 yılında ise göl yüzey alanının bir miktar $\left(6.35 \mathrm{~km}^{2}\right)$ genişlediği, 2020 y1lında ise göl alanının tekrar küçülme dönemine girdiği gözlenmiştir (Şekil 4). MNDWI yöntemi ile hesaplanan göl yüzey alanlarının değişim yüzdesi hesaplandığında; 35 yıllık süreçte gölde $\% 93.78$ oranında küçülme olduğu belirlenmiştir (Şekil 3).

1985 yılından günümüze kadar göl alanı genel olarak giderek küçülme eğiliminde olsa da bazı yıllarda göl yüzey alanında artışlar gözlenmiştir (Şekil 4). Seyfe Gölü'nü çevreleyen topoğrafya ile göl alanı arasındaki yükselti farkının az olması nedeniyle göl seviye ve göl yüzey alanındaki değişimler hızlı ve görünür bir şekilde fark edilmektedir. MNDWI analiz sonuçlarına göre; gittikçe küçülmekte olan göl alanının 2015 yılında 
yayılımının arttığı görülmektedir (Tablo 3). Bu artışa neden olabilecek faktörler arasında gölün
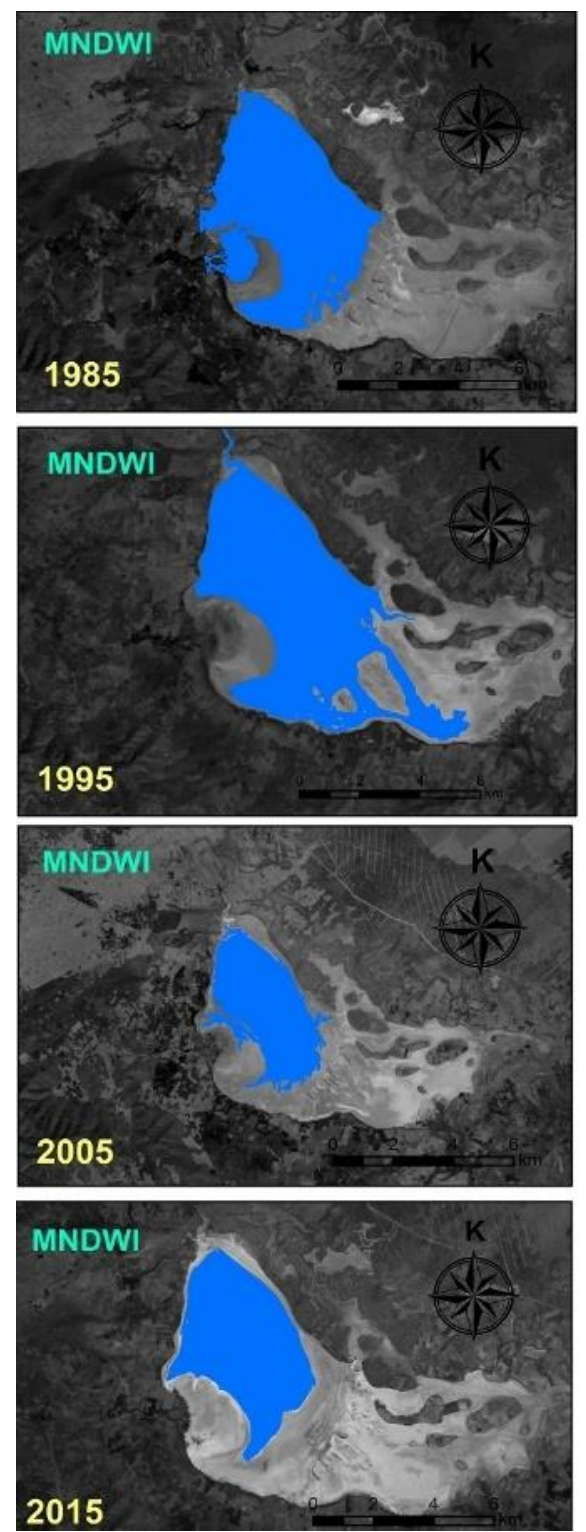

beslenim ve boşalım bileşenlerinden yağış ve buharlaşmanın etkisi olabileceği düşünülmektedir.
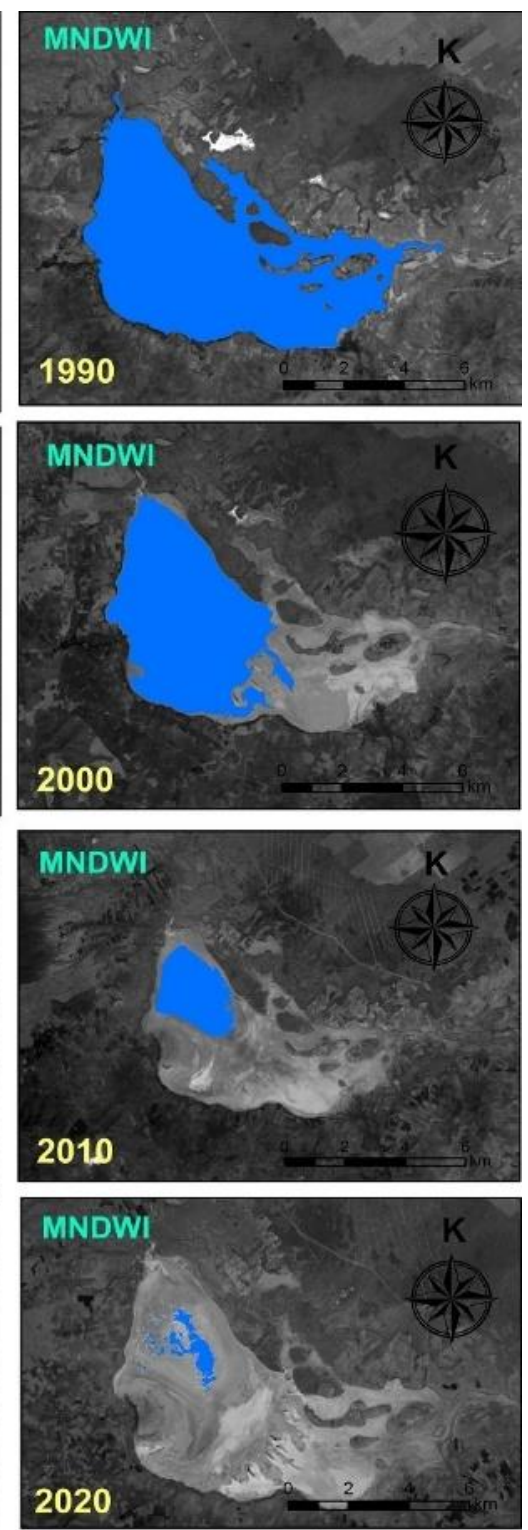

Şekil 3. Seyfe Gölü yüzey alanının MNDWI yöntemi ile belirlenen 1985-2020 yılları arasındaki değişimi

Tablo 3. Seyfe Gölü’nün yıllara göre alansal değişim miktarı

\begin{tabular}{ccccc}
\hline Tarih & $\begin{array}{c}\text { MNDWI-Göl } \\
\left.\text { alanı ( } \mathbf{k m}^{2}\right)\end{array}$ & $\begin{array}{c}\text { Alansal değişim } \\
\text { tarihi }\end{array}$ & $\begin{array}{c}\text { Dönemsel } \\
\text { değişim } \\
\left.\text { miktarı } \mathbf{( k m}^{2}\right)\end{array}$ & $\begin{array}{c}\text { Başlangıçtaki } \\
\text { alana göre değişim } \\
\text { yüzdesi }(\%)\end{array}$ \\
\hline 23.09 .1985 & 29.89 & & & \\
21.09 .1990 & 66.87 & $1985-1990$ & 36.98 & 123.69 \\
05.10 .1995 & 33.25 & $1990-1995$ & -33.62 & 11.24 \\
16.09 .2000 & 36.72 & $1995-2000$ & 3.47 & 22.85 \\
14.09 .2005 & 20.98 & $2000-2005$ & -15.74 & -29.81 \\
28.09 .2010 & 11.82 & $2005-2010$ & -9.16 & -60.46 \\
26.09 .2015 & 18.17 & $2010-2015$ & 6.35 & -39.21 \\
23.09 .2020 & 1.86 & $2015-2020$ & -16.31 & -93.78 \\
\hline
\end{tabular}


$\mathrm{Bu}$ yaklaşımın sonucunda göl alanına düşen yağış miktarının artışa geçtiği ve buharlaşma miktarının azaldığı yıllarda gölün alansal yayılımının artması beklenmektedir. Bu kapsamda; çalışma alanında gerçekleştirilen hidrolojik ve hidrojeolojik incelemeler ile göl alanına en yakın istasyon olan Kırşehir Meteoroloji Gözlem İstasyonu'nun (KMGI) yağış ve buharlaşma verileri değerlendirilmiştir. KMGİ verilerine göre; 19302020 yılları arasındaki uzun yıllar ortalama yağış miktarı $377.44 \mathrm{~mm} / \mathrm{y}$ l olarak hesaplanmıştır. Yağışlı ve kurak periyotlar ortalama 6-7 y1l sürmekte olup, 70 y1llık dönemde maksimum düşen yıllık yăğıs miktarı 1987 yılında 541.9 $\mathrm{mm} / \mathrm{y} 1$ l'dır. 2015 yılında düşen yıllık yağış miktarı ise $471.4 \mathrm{~mm} / \mathrm{y} 1 \mathrm{l}$ olarak ölçülmüştür (Şekil 4). Açık yüzey buharlaşma verilerine göre ise 1971-2020 yılları arasında ölçülen yıllık ortalama buharlaşma miktarı $1336.4 \mathrm{~mm}$ olarak hesaplanmıştır. Maksimum buharlaşma miktarı 2007 yılında $1933.8 \mathrm{~mm}, 2010$ ve 2015 y1llarında ölçülen buharlaşma miktarları ise sirasıyla $1514.9 \mathrm{~mm}$ ile 1230 mm'dir (Tablo 4).

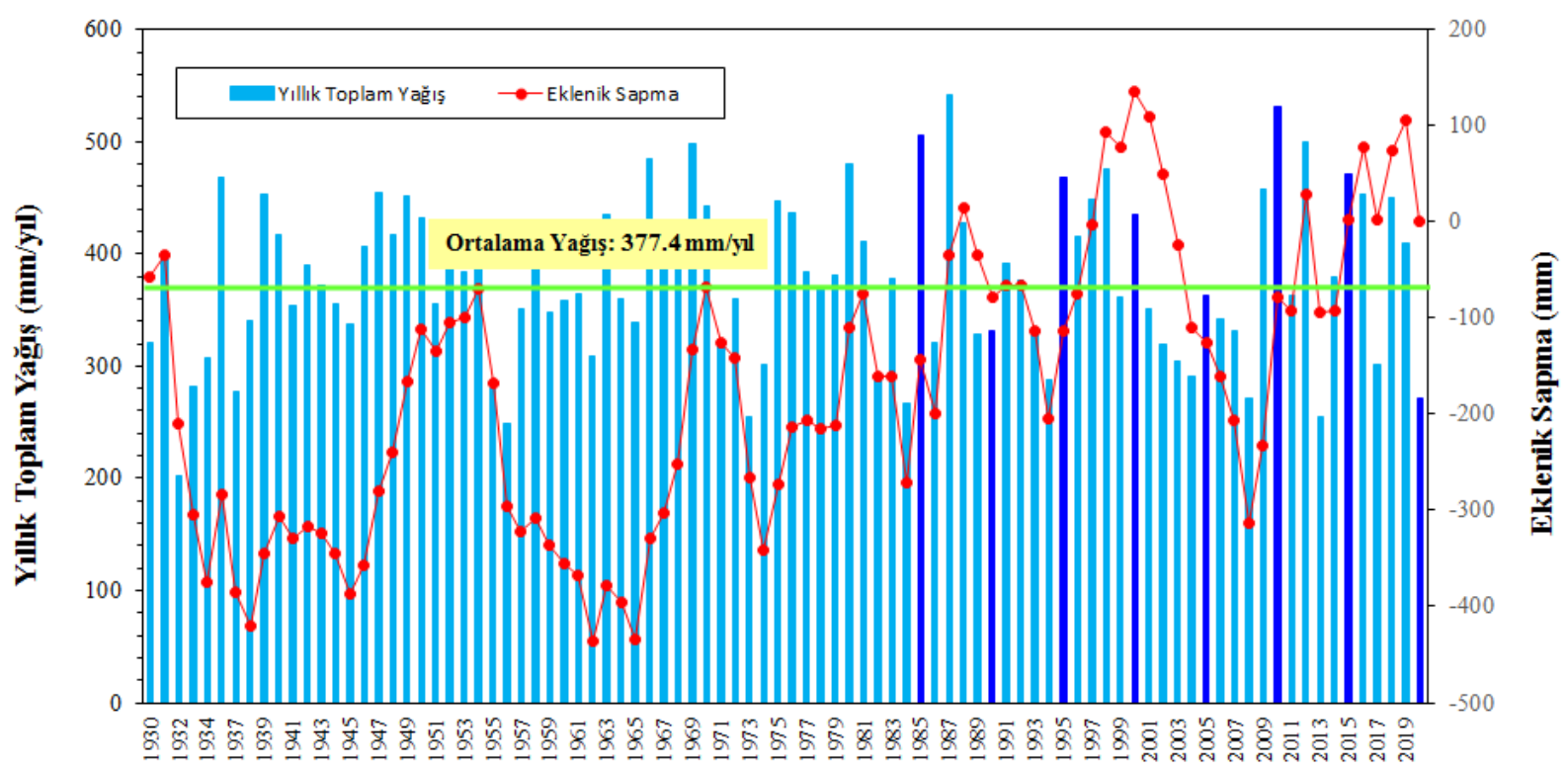

Zaman (Yll)

Şekil 4. Kırşehir Meteoroloji Gözlem İstasyonu'na ait y1llık toplam yağış, ortalama yağış ve eklenik sapma grafiği

KMGİ verilerine göre; 2013 y1lından itibaren y1llık düşen yağış miktarının arttığı ve 2015 yılında bu yağışlı dönemin etkisinin görüldüğü, yağış ve buharlaşma verilerinin alansal büyümeyi desteklediği belirlenmiştir (Tablo 4).

Tablo 4. Seyfe Gölü yüzey alanının meteorolojik verilerle (yıllık toplam yağış ve buharlaşma) ilişkisi

\begin{tabular}{cccc}
\hline Yıllar & Yıllık yağış (mm) & Buharlaşma $(\mathbf{m m})$ & Yüzey alanı $\left(\mathbf{k m}^{\mathbf{2}}\right)$ \\
\hline 1985 & 506.0 & 1428.3 & 29.89 \\
1990 & 331.9 & 1321.5 & 66.87 \\
1995 & 468.8 & 1372.6 & 33.25 \\
2000 & 434.9 & 1407.5 & 36.72 \\
2005 & 362.9 & 1466.0 & 20.98 \\
2010 & 531.2 & 1514.9 & 11.82 \\
2015 & 471.4 & 1230.0 & 18.17 \\
2020 & 271.0 & 1436.8 & 1.86 \\
\hline
\end{tabular}

Bununla birlikte göl havzasında gerçekleştirilen hidrojeolojik araştırmalar kapsamında; 1990 yılından itibaren inşa edilen drenaj kanalları; 2000'li y1llardan itibaren akifer birimler içerisinde çok fazla sondaj kuyusunun açılması ve gölü besleyen kaynakların, mevsimlik derelerin zaman 
içerisinde kuruması gibi nedenlerden dolayı tarihsel süreçte göle katılan su miktarında azalmalar olduğu belirlenmiştir. Dolayısıyla zaman içerisinde gölün doğal beslenim boşalım dengesine etki eden bileşenlerin değiştiği saptanmıştır. $\mathrm{Bu}$ kapsamda düşen yağış miktarının fazla, buharlaşma miktarının az olduğu; fakat göl yüzey alanında büyümenin görülmediği, aksine küçüldüğü yılları ve periyotları (yağış11-kurak) yukarıda belirtilen doğal ve yapay faktörlerin birlikte değerlendirilerek ele alınması gerekmektedir (Tablo 4). Fakat çalışma alanına konu olan göl yüzey alanının değişimine neden olacak iklimsel ve antropojenik etkilerin nedenleri, hangi faktörün göl alanının değişiminde ne kadar etkili olduğu ve bu sürecin sonuçları bu çalışma kapsamında değerlendirilmemiştir.

\subsection{Göl batimetrisi}

Göl batimetrisi çalışmaları kapsamında DSİ (2015) tarafından hazırlanan 1/20.000 ölçekli Seyfe Gölü hidrografik haritası değerlendirilerek göl batimetri haritası oluşturulmuştur. Göl alanı üzerinde 1244 noktada göl derinlik ölçümü yapılmıștır. Göl alanının 3 boyutlu analizi CBS ortamında ArcMap 10.4.1 yazılımı ile gerçekleştirilmiştir Göl alanının batimetri haritasının oluşturulma basamaklarına ilişkin süreçleri gösteren akış şeması Şekil 5'de verilmiştir.

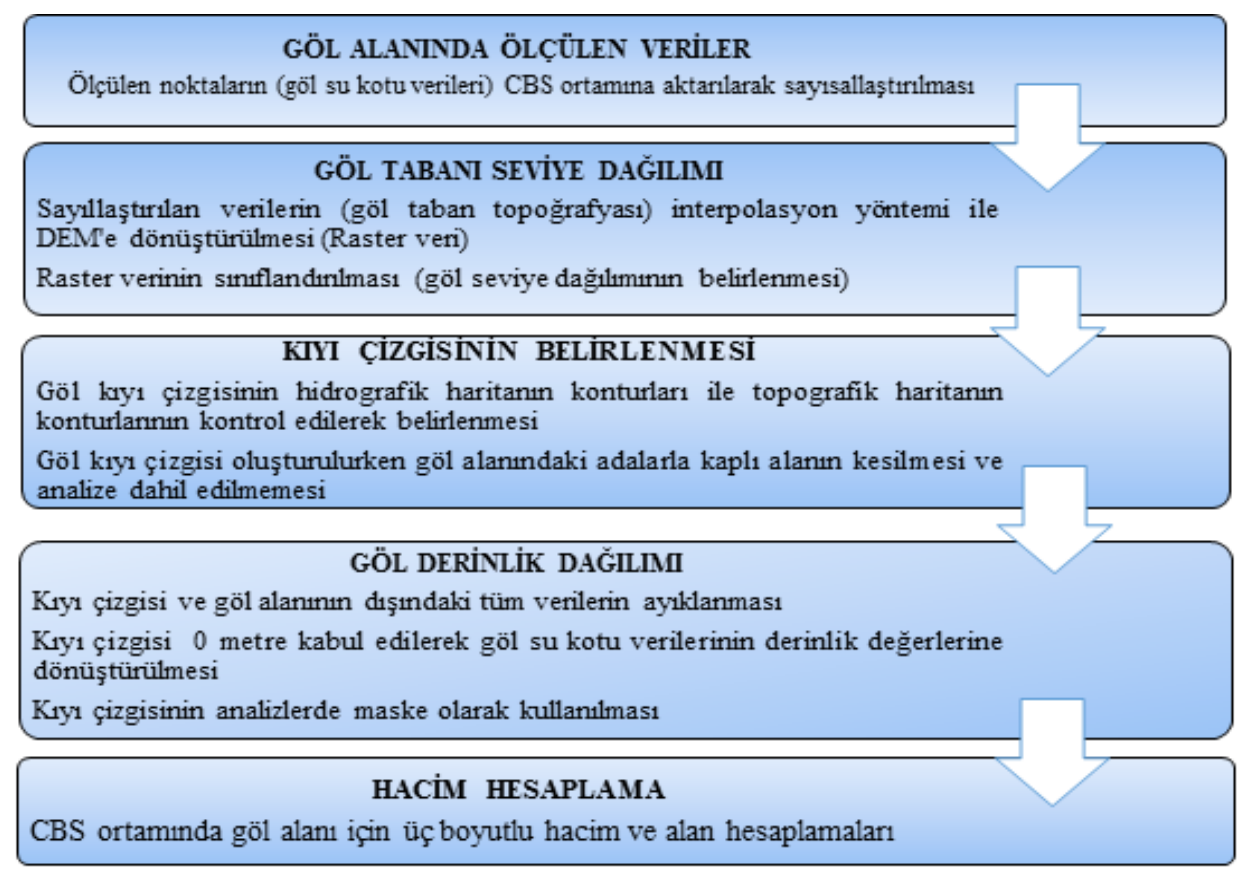

Şekil 5. Göl batimetri haritası oluşturulma basamakları

Öncelikle göl alanı hidrografik haritası ile göl tabanının deniz seviyesinden yüksekliğini temsil eden göl su kotu verileri ArcMap 10.4.1 yazılımına aktarılarak sayısallaştırılmıştır. Bu kapsamda göl seviye kotunu temsil eden noktasal veriler Kriging interpolasyon yöntemi ile dağıtılarak alanın göl su seviye dağılımını gösteren göl taban topoğrafyası oluşturulmuştur.

DSİ tarafından göl alanından toplanmış göl su seviye verileri, göl taban topoğrafyası ile karşılaş̧tırılarak kontrol edilmiş ve gölün yükseklik dağılımı ile uyumu incelenmiştir. Yine göl alanının sayısal yükseklik dağılımı, topoğrafik haritalardan da yararlanılarak kontrol edilmiş, göl kıyı çizgisi içerisinde temsil edici olmayan veriler ayıklanmıştır.
Göl alanı kıyı çizgisi ise, 1997 y1lına ait 1/25.000 ölçekli topoğrafik haritalardan, göl hidrografik haritasından ve MNDWI yöntemine göre 2015 y1lı için belirlenmiş göl kıyı çizgisi ile karşılaştırılarak kontrol edilmiş ve göl kıyı sınırı belirlenmiştir. Göl taban topoğrafyası oluşturulurken, göl kıyı çizgisi dışındaki ölçülmüş tüm veriler maskelenmiş ve alanının doğusunda yer alan adaların yer aldığ 1 bölge analize dahil edilmemiştir. Göl alanında 2015 yılı Ağustos ayı için en yüksek su seviyesi $1116.63 \mathrm{~m}$, en düşük su seviyesi ise $1113.03 \mathrm{~m}$ olarak bulunmuştur. Analize dahil edilmeyen adalar bölgesinde ise göl taban seviyesi en yüksek $1122.53 \mathrm{~m}$ olarak hesaplanmıştır.

Göl taban topoğrafyasındaki göl seviye kotu değerleri derinlik değerlerine dönüştürülmüş ve ArcMap 10.4.1 yazılımında Kriging interpolasyon yöntemi ile dağıtılarak alanın batimetri haritası 
oluşturulmuştur (Şekil 6). 1997 yılına ait 1/25.000 ölçekli topoğrafik harita ile hidrografik haritadaki 1115 m eş yükseklik eğrisi göl kıyı sınırı olarak belirlenmiştir. Referans düzeyi olarak belirlenen $1115 \mathrm{~m}$, sifir metre $(0 \mathrm{~m})$ olarak kabul edilerek, kiyı çizgisi dışında kalan tüm derinlik değerleri maskelenmiştir.
Göl sığ bir göl olup, 2015 yılı Ağustos ayında gölün en derin yeri $1.95 \mathrm{~m}$ ile alanın kuzeyi olarak belirlenmiştir. Gölün güneyinde kıyı çizgisinden yaklaşık $2.5 \mathrm{~km}$ sonrasında, batısında ise $1.5 \mathrm{~km}$ sonrasında gölün en derin yerine ulaşılmaktadır (Şekil 6).

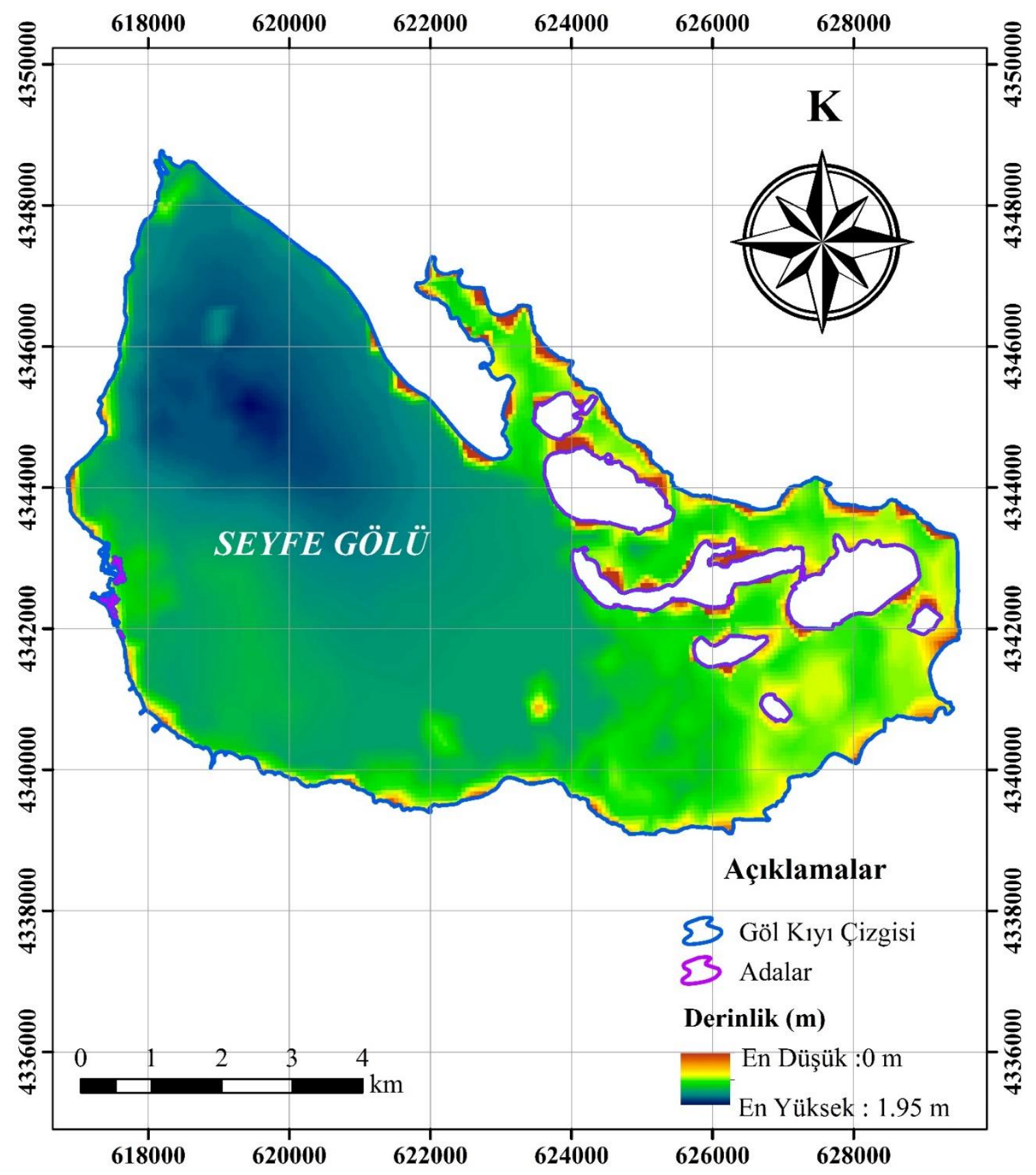

Şekil 6. Seyfe Gölü batimetri haritası

Ayrıca ArcMap 10.4.1 yazılımının üç boyutlu analiz modülünün fonksiyonel yüzey oluşturma ve hacim hesaplama komutu ile göl taban topoğrafyasını temsil eden sayısal yükseklik modeli kullanılarak göl alanının çeşitli kotlardaki hacimsel ve alansal değişimleri hesaplanmıştır (Tablo 5).
Bu kapsamda Seyfe Gölü'nün göl taban kotundan itibaren $0.5 \mathrm{~m}$ artan derinlikle değişen yüzey alanları ve hacimleri hesaplanmış ve Tablo 5 'te verilmiştir. 
Tablo 5. Seyfe Gölü alan-hacim-derinlik ve göl seviye kotu değişimi

\begin{tabular}{cccc}
\hline Göl kotu $(\mathbf{m})$ & Derinlik $(\mathbf{m})$ & Alan $\left(\mathbf{k m}^{\mathbf{2}}\right)$ & Toplam hacim $\left(\mathbf{k m}^{\mathbf{3}}\right)$ \\
\hline 1113.00 & 0.0 & 0.00 & 0.00 \\
1113.50 & 0.5 & 3.95 & 0.0003 \\
1114.00 & 1.0 & 27.61 & 0.01 \\
1114.50 & 1.5 & 46.06 & 0.03 \\
1115.00 & 2.0 & 58.54 & 0.05 \\
1115.50 & 2.5 & 60.52 & 0.08 \\
1116.00 & 3.0 & 60.93 & 0.11 \\
1116.50 & 3.5 & 61.01 & 0.14 \\
1117.00 & 4.0 & 61.02 & 0.17 \\
\hline
\end{tabular}

Geçmiş yıllarda 1995-2003 yılları arasında ölçülen göl seviye verileri batimetri çalışmaları ile birlikte değerlendirildiğinde (DSİ, 2004); minimum göl su seviyesi 2002 yılı Ekim ayında 1113.55 m, maksimum göl su seviyesi 1996 yılı Mayıs ayında $1114.79 \mathrm{~m}$, ortalama göl su seviyesi ise $1114.18 \mathrm{~m}$ olarak belirlenmiştir (Şekil 7).

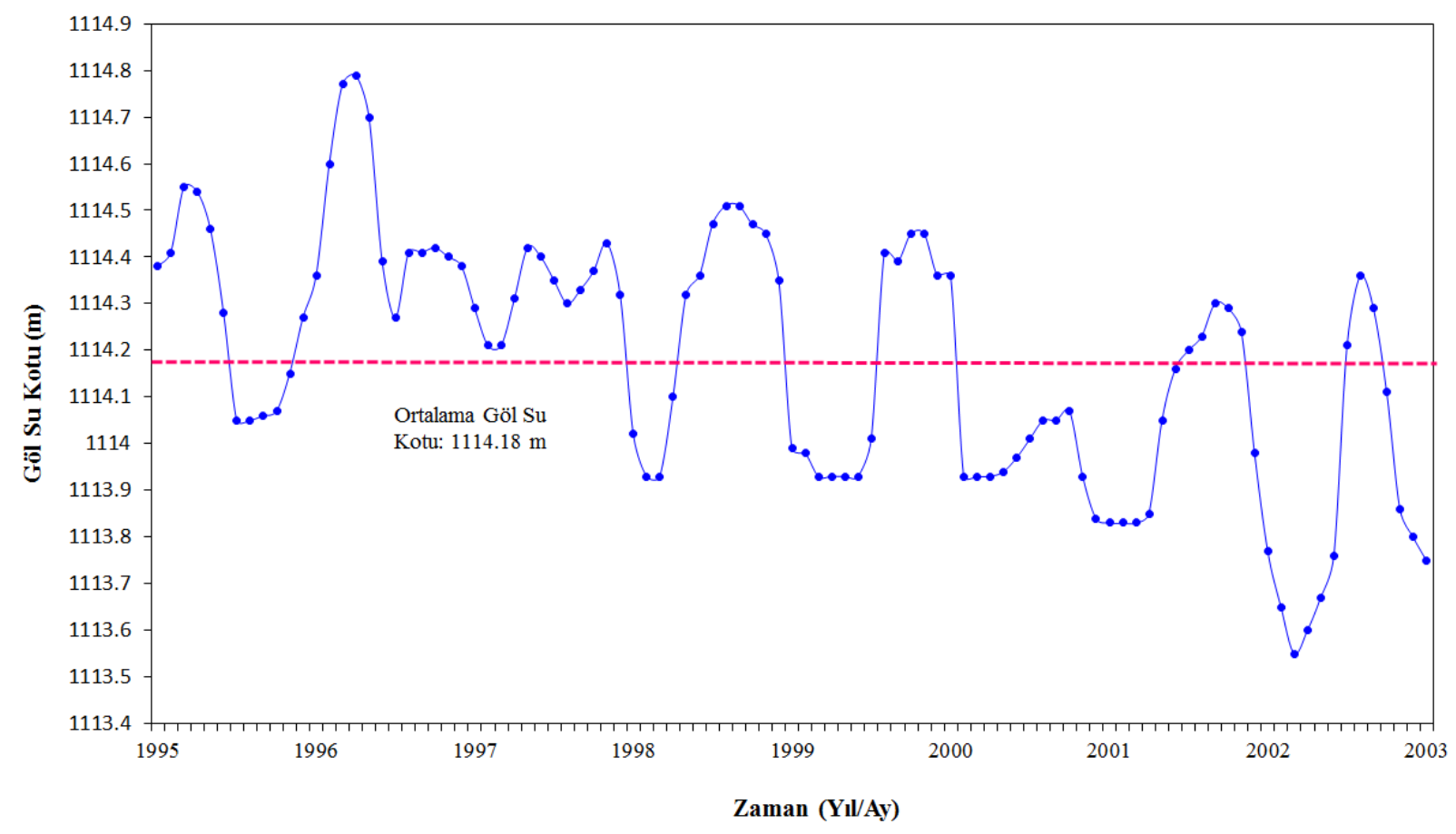

Şekil 7. 1995-2003 yılları arası göl seviye değişimleri

$\mathrm{Bu}$ verilere göre; minimum ve maksimum göl yüzey alanları sırasıyla $6 \mathrm{~km}^{2}(1113.55 \mathrm{~m})$ ile 56 $\mathrm{km}^{2}(1114.79 \mathrm{~m})$ arasında değişmektedir. Ortalama göl alanı ise $34 \mathrm{~km}^{2}(1114.18 \mathrm{~m})$ olarak hesaplanmıştır. Minimum ve maksimum göl hacimleri ise sirasiyla $0.0002 \mathrm{~km}^{3}$ ile $0.044 \mathrm{~km}^{3}$ olarak hesaplanmıștır. Ortalama göl hacmi ise $0.016 \mathrm{~km}^{3}(1114.18 \mathrm{~m})$ 'tür. Göl su seviye değişimleri incelendiğinde en düşük göl su seviyeleri Eylül ayında gözlenirken; en yüksek göl seviyeleri Nisan-Mayıs aylarında gözlenmektedir (Şekil 7). Ayrıca çalışma alanında MNDWI yöntemine göre 1985-2020 yılları için hesaplanan göl yüzey alanlarına karşılık gelen göl seviye kotları ve göl hacimleri hesaplanmıştır (Tablo 6).

\section{Tartışma ve sonuçlar}

Bu çalışmada UA ve CBS teknikleri kullanılarak beş yıllık periyotlar halinde 1985-2020 yılları arasında Seyfe Gölü yüzey alanı değişimi Landsat uydu görüntüleri kullanılarak MNDWI yöntemi ile belirlenmiş ve göl batimetri çalışmaları ile birlikte değerlendirilmiştir.

Göl batimetri çalıșmaları kapsamında ise göl taban topoğrafyası için oluşturulan sayısal yükseklik dağılımı kullanılarak farklı göl seviye kotlarındaki alansal ve hacimsel değişimler CBS ortamında hesaplanmış ve MNDWI yöntemi sonuçları ile birlikte değerlendirilmiştir. 
Tablo 6. MNDWI yöntemi ile hesaplanan göl alanının hacim ve göl seviye kotu değişimi

\begin{tabular}{cccc}
\hline Tarih & Göl su kotu $(\mathbf{m})$ & Alan $\left(\mathbf{k m}^{\mathbf{2}}\right)$ & Toplam hacim $\left.\mathbf{( k m}^{\mathbf{3}}\right)$ \\
\hline 23.09 .1985 & 1114.15 & 29.89 & 0.08 \\
21.09 .1990 & 1118.1 & 66.87 & 0.18 \\
05.10 .1995 & 1114.25 & 33.25 & 0.088 \\
16.09 .2000 & 1114.3 & 36.72 & 0.1 \\
14.09 .2005 & 1113.8 & 20.98 & 0.056 \\
28.09 .2010 & 1113.7 & 11.82 & 0.032 \\
26.09 .2015 & 1113.9 & 18.17 & 0.048 \\
23.09 .2020 & 1113.5 & 1.86 & 0.0004 \\
\hline
\end{tabular}

İncelenen yıllara karşılık gelen göl su kotu ve hesaplanan göl alanı ve hacim değerleri Şekil 8'de verilmiştir.

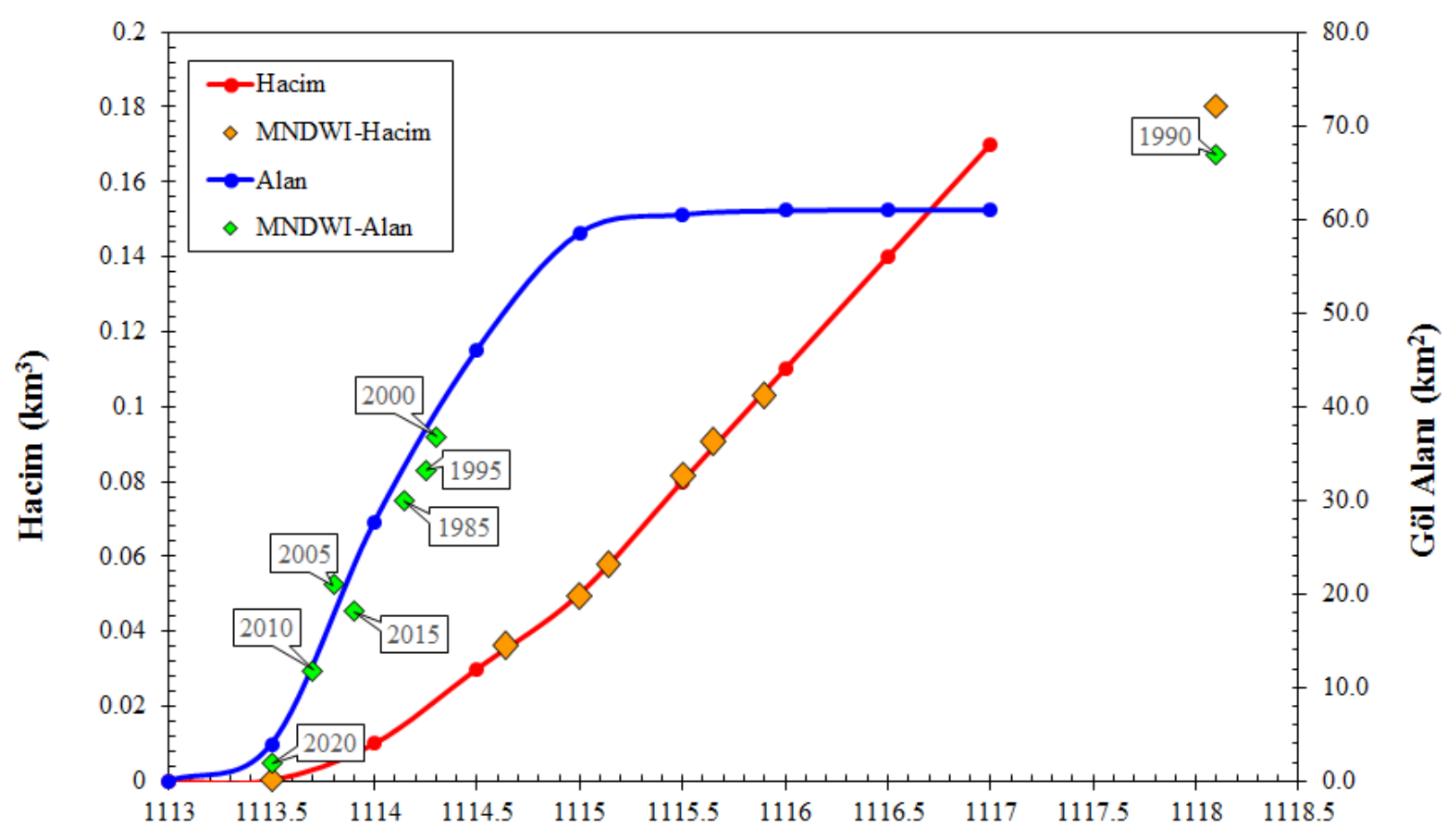

Göl Su Kotu (m)

Şekil 8. Göl alanı için kot, alan ve hacim ilişkisi

Çalışmanın amacına yönelik seçilen MNDWI yöntemine göre yapılan analizde, gölün 1990 yılında maksimum yüzey alanına ulaştığı belirlenmiştir. 1985-2020 y1lları için hesaplanan göl yüzey alanlarına karşılık gelen göl seviye kotlarının 2000'li yıllardan itibaren giderek düştüğü gözlemlenmiştir. Bazı yıllarda ise düşen yağış miktarına bağlı olarak göl seviye kotunda yükselimlerin gerçekleştiği belirlenmiştir. Seçilen zaman serisi için göl yüzey alanının $\% 93.78$ oranında azaldığı hesaplanmıştır. Göl batimetri haritasına göre gölün en derin yeri alanın kuzeyi olarak belirlenmiştir.

Çalışmaya konu olan Seyfe Gölü kapalı bir havzada yer almaktadır ve göl alanının beslenimine katk1 sağlayan en önemli bileşeni yağıştır. Bu bağlamda 2015 yılında göl yüzey alanının büyümesinde göle düşen yıllık yağış miktarındaki artışın etkili olduğu düşünülmektedir. Göl alanında yapılmış çalışmalar (Reis ve Y1lmaz, 2008; Yaman ve Avdan, 2018) değerlendirildiğinde; göl yüzey alanı değişiminin saptanmasında farklı yıllar için farklı yöntemler (kontrolsüz sınıflama ve NDWI) uygulanmış olsada; tüm çalışmalarda ortak sonuç olarak göl alanının gittikçe küçüldüğü ve göl su rezervinin azaldığını göstermektedir.

Seyfe Gölü'nde 35 yıllık süreçte artan bir hızla alan kaybının gerçekleştiği görülmektedir. $\mathrm{Bu}$ sürecin önlenebilmesi çok olası olmamakla birlikte; alansal kaybın yavaşlatılması anlamında bazı acil 
planlamaların yapılması gerektiği düşünülmektedir. Gerek iklimsel etkiler gerekse antropojenik etkiler gölün doğal halindeki beslenim boşalım dengesinin bozulmasında önemli rol oynamaktadır. Bununla birlikte gölün seviye ve alan kayıplarını açıklamak için sadece iklimsel bileşenlerde gerçekleşen değişimlerden kaynaklı bir sürecin olmadığını, gölün beslenme alanı içerisinde gerçekleştirilen yapay müdahalelerden (kuyularla çekim, sulama, drenaj kanalları, tarım deseni, arazi kullanımı vb.) doğrudan etkilendiği düşülmektedir. Gölü besleyen su kaynaklarının yoğun ve bilinçsiz şekilde kullanımı, olumsuz iklim koşulları ile birleştiğinde son yıllarda gözlendiği üzere gölün tamamen kurumasına yol açma riski olduğu düşünülmektedir.

Ayrıca göl alanı ve çevresi çeşitli koruma statülerine alınmış olduğu halde günümüzde göldeki alansal ve hacimsel kaybı önleyecek yönde bir sürecin gelişmediği de görülmektedir. Dolayısıyla gölün korunması, iyileştirilmesi ve yönetimi anlamında da göl yüzey alanının değişimine etkiyen doğal ve yapay faktörler belirlenmeli, göl havzası içerisinde hangi bileşenin daha fazla etkisi olduğu ortaya konulmalıdır. Alınacak tedbirlerin bu faktörler gözetilerek alınması gölün sürdürülebilirliği için büyük önem taşımaktadır.

$\mathrm{Bu}$ çalışmanın ilerletilmesine yönelik çalışmalar kapsamında ise çeşitli uydulara (Sentinel, Spot vb.) ait yersel çözünürlüğü daha yüksek uydu görüntüleri ile çalışılarak farklı yıllar ve farklı periyotlar için gölün alansal yayılımındaki değişiminin belirlenebileceği düşünülmektedir. Bunun yanısıra çeşitli uyduların gelişmiş sensörleri ile göl alanındaki ve göl su kotundaki değişimlerin farklı parametreler ile (göl yüzey sıcaklığı, altimetrik kot değişimi vb.) değerlendirilmesi mümkün olabilecektir. Yine çözünürlüğü daha yüksek uydu görüntülerinin ve türev verilerinin kullanılması ile elde edilecek sonuçların hata payı daha düşük olacağı için göl seviye, alan ve hacim parametrelerinin doğal sistemi daha iyi temsil edebileceği düşünülmektedir.

\section{Teşekkür}

Bu çalışma yazarlardan Cansu Yurteri'nin doktora tez çalışmasının bir bölümünü kapsamaktadır. Yine bu çalışma Hacettepe Üniversitesi Bilimsel Araştırma Projeleri Koordinasyon Birimi tarafindan (Proje No: 18960-2021) desteklenmektedir. Yazarlar Landsat uydu görüntüleri için Amerika Birleşik Devletleri Jeolojik Araştırma Merkezi'ne (USGS), meteorolojik veriler için Tarım ve Orman Bakanlığı Meteoroloji Genel Müdürlüğü’ne, metnin yazımı sırasındaki öneri, görüş ve katkıları için Dr. Hayati Koyuncu'ya, makale metninin son haline gelmesindeki öneri, görüş ve katkıları için editör ve hakemlere teşekkür eder.

\section{Kaynaklar}

Ali, M., Dirawan, G., Hasim, A. and Abidin, M. (2019). Detection of changes in surface water bodies urban area with NDWI and MNDWI methods. International Journal on Advanced Science, Engineering and Information Technology, 9, 946. https://doi.org/10.18517/ijaseit.9.3.8692.

Bao, Y. and Zhang, X. (2011). The study of lakes dynamic change based on RS and GIS-take Dalinor Lake as an example. Procedia Environmental Sciences, 10, 2376-2384. https://doi.org/10.1016/j.proenv.2011.09.370.

Chang, B., He, K., Li, R., Sheng, Z. and Wang, H. (2017). Linkage of climatic factors and human activities with water level fluctuations in Qinghai Lake in the northeastern Tibetan Plateau, China. Water, $9(7), \quad 552$. https://doi.org/10.3390/w9070552.

Deus, D. and Gloaguen R. (2013). Remote sensing analysis of lake dynamics in semi-arid regions: implication for water resource management. Lake Manyara, East African Rift, northern Tanzania. Water, 5(2), 698-727. https://doi.org/10.3390/w5020698.

Dost, R.J.J. and Mannaerts, C.M. (2008). Generation of lake bathymetry using sonar, satellite imagery and GIS. J. Dangermond (Ed.), ESRI 2008: Proceedings of the 2008 ESRI International User Conference (pp. 1-5). Redmond: ESRI.

DSİ, (2004). Seyfe Ovast hidrojeolojik revize etüt raporu. Kayseri: Devlet Su İşleri XII Bölge Müdürlüğü, Jeoteknik Hizmetler ve Yeraltı Suları Dairesi Başkanlığı.

DSİ, (2015). Seyfe Gölü hidrografik haritası. Ankara: Devlet Su İşleri Etüt, Planlama ve Tahsisler Dairesi Başkanlığı.

El Asmar, H., Hereher, M. and Kafrawy, S. (2013). Surface area change detection of the Burullus Lagoon, north of the Nile Delta, Egypt, using water indices: a remote sensing approach. The Egyptian Journal of Remote Sensing and Space Science, $\quad$ 16(1), https://doi.org/10.1016/j.ejrs.2013.04.004.

Fang Fang, Z., Bing, Z., Jun Sheng, L., Qian, S., Yuan Feng, W. and Yang, S. (2011). Comparative analysis of automatic water identification method based on multispectral remote sensing. Procedia 
Environmental Sciences, $11, \quad 1482-1487$. https://doi.org/10.1016/j.aqpro.2015.02.095.

Howari, F., Sherif, M., Singh, V. and Alasam Alzaabi, M. (2007). Application of GIS and Remote Sensing techniques in identification, assessment and development of groundwater resources. Thangarajan, M. (Eds.), Groundwater. (pp. 125). Germany, Netherlands: Springer.

Gao, B.C. (1996). NDWI-A normalized difference water index for remote sensing of vegetation liquid water from space. Remote Sensing of Environment, $\quad 58, \quad 257-266$. https://doi.org/10.1016/S0034-4257(96)00067-3

Gautam, V., Gaurav, P., Murugan, P. and Annadurai, M. (2015). Assessment of surface water dynamics in Bangalore using WRI, NDWI, MNDWI, supervised classification and K-T transformation, Aquatic Procedia, 4, 739-746.

Gülci, S., Gülci, N. ve Yüksel, K. (2019). Aslantaş Baraj Gölü ve çevresinin su yüzey alanı ve arazi örtüsü değişiminin Landsat uydu görüntüleri kullanılarak izlenmesi. Journal of the Institute of Science and Technology, 9(1), 100-110. https://doi.org/10.21597/jist.419221.

Haibo, Y., Zongmin. W., Hongling, Z. and Yu, G. (2011). Water body extraction methods study based on RS and GIS. Procedia Environmental Sciences, $\quad 10, \quad 2619-2624$. https://doi.org/10.1016/j.proenv.2011.09.407.

Kiage, L. and Douglas, P. (2019). Linkages between land cover change, lake shrinkage, and sublacustrine influence determined from remote sensing of select Rift Valley Lakes in Kenya. Science of the Total Environment, 709, 136022. https://doi.org/10.1016/j.scitotenv.2019.136022

McFeeters, S.K. (1996). The use of normalized difference water index (NDWI) in the delineation of open water features. International Journal of Remote Sensing, 17, 1425-1432. https://doi.org/10.1080/01431169608948714.

Mutlu, A., Kazanc1, B., Özçetin, A. ve Sarıyılmaz, F. (2020). Akşehir Gölü zamansal değişiminin bant oranlama yöntemleri ile belirlenmesi. Türkiye Uzaktan Algilama Dergisi, 2(1), 22-28. https://dergipark.org.tr/tr/pub/tuzal/issue/52699/ 650018.

Naik, B. and Anuradha, B. (2018). Extraction of waterbody area from high-resolution Landsat imagery. International Journal of Electrical and Computer Engineering, 8, 4111. https://doi.org/10.11591/ijece.v8i6.pp.41114119.

Nandi, D., Chowdhury, R., Mohapatra, J., Mohanta, K. and Ray, D. (2019). Automatic delineation of water bodies using multiple spectral indices. International Journal of Scientific Research in Science, Engineering and Technology, 4, 498512.

Reis, S. and Y1lmaz, H.M. (2008). Temporal monitoring of water level changes in Seyfe Lake using remote sensing. Hydrological Processes, 22, 4448-4454. https://doi.org/10.1002/hyp.7047.

Sayhan, H. (2001). Seyfe Gölü eski seviyelerinin Kuvaterner jeomorfolojisi açısından etüdü. Gazi Üniversitesi Kırşehir Eğitim Fakültesi Dergisi, 2(2), 55-73.

URL-1,

https://bolge9.tarimorman.gov.tr/Menu/85/Kirse hir-Seyfe-Golu-Ramsar-Alani. 12 Temmuz 2021.

URL-2, https://earthexplorer.usgs.gov. 12 Temmuz 2021.

$\mathrm{Xu}$, H. (2006). Modification of normalized difference water index (NDWI) to enhance open water features in remote sensed imagery. International Journal of Remote Sensing, 27(14), 3025-3033. https://doi.org/10.1080/01431160600589179.

Yaman, M. ve Yigit Avdan, Z. (2018). Uydu görüntüleri kullanılarak su kütlesi değişiminin izlenmesi: Seyfe Gölü örneği. 2018 VII. Uzaktan Algılama ve CBS Sempozyumu (UZAL-CBS), Eskişehir.

Zhai, K., Wu, X., Qin, Y. and Du, P. (2015). Comparison of surface water extraction performances of different classic water indices using OLI and TM imageries in different situations. Geo-spatial Information Science, 18, 32-42.

https://doi.org/10.1080/10095020.2015.1017911

Zhou, W., Li, Z., Ji, S., Hua, C. and Fan, W. (2015). A new index model NDVI-MNDWI for water object extraction in hybrid area. Bian, F., Xie, Y. (eds), Communications in Computer and Information Science (s. 513-519.). Berlin: Springer. https://doi.org/10.1007/978-3-66245737-5_51. 